\title{
Reframing the Nineteenth Century
}

Reenquadrar o século XIX

Recadrer le XIX ${ }^{e}$ siècle

Rochelle Pinto, Sidh Losa Mendiratta and Walter Rossa

\section{OpenEdition}

\section{Journals}

Electronic version

URL: http://journals.openedition.org/rccs/7006

DOI: $10.4000 /$ rccs. 7006

ISSN: 2182-7435

Publisher

Centro de Estudos Sociais da Universidade de Coimbra

\section{Printed version}

Date of publication: 1 May 2018

Number of pages: 93-112

ISSN: 0254-1106

\section{Electronic reference}

Rochelle Pinto, Sidh Losa Mendiratta and Walter Rossa, «Reframing the Nineteenth Century », Revista Crítica de Ciências Sociais [Online], 115 | 2018, Online since 15 May 2018, connection on 19 April 2019. URL : http://journals.openedition.org/rccs/7006 ; DOI : 10.4000/rccs.7006 


\section{ROCHELLE PINTO, SIDH LOSA MENDIRATTA, WALTER ROSSA}

\section{Reframing the Nineteenth Century}

No longer determined exclusively by the economic fortunes of the empire, the history of the nineteenth-century Portuguese colonies in India and the Indian Ocean region has been sufficiently elaborated for some heuristic frameworks to emerge. Histories of medicine, anthropology, politics, print, migration and slavery underscore the importance of non-statist narratives as they trace the movement of people, goods and ideas along formal and informal networks, often under the ascendant British colonial power. Along with studies on visual and spatial culture and agrarian policy, these narratives have helped delineate distinctive and contesting attributes that characterise the nineteenth century. The century continues to pose a historiographic challenge as it both draws from and contests the dominant theoretical accounts of colonialism.

Keywords: castes; colonialism; Goa; Portuguese empire; science.

This dossier of the Revista Critica de Ciências Sociais (RCCS) was conceived both to draw attention to the directions taken in recent work on the history and historiography of Portuguese colonialism in nineteenth-century India and to reflect upon the scope and contours of past publications. ${ }^{1}$ The theme emerged as a response to the perceived tendency to associate the nineteenth century with the empire's focus on Africa in the 1800s. This characterises the field as a whole (both within the Centre for Social Studies of the University of Coimbra and the RCCS and beyond it), as it follows the direction of the colonial state's financial and political interests in different territories. However, a number of publications focusing on East Africa and Portuguese territories in India offer compelling theories for the historical understanding of areas that fall outside the immediate economic interest of the state.

The initial call for papers therefore proposed a wider horizon for the dossier and hoped to include dimensions of the Portuguese colonial presence in the

\footnotetext{
${ }^{1}$ This was undertaken as a part of the postdoctoral project "Framing Identity: Cityscapes and Architecture of Mumbai's Catholic Communities ( $16^{\text {th }}-20^{\text {th }}$ centuries)", by Sidh Losa Mendiratta, supervised by Walter Rossa and Rochelle Pinto, and funded by Fundação para a Ciência e a Tecnologia (SFRH/BPD/89298/2012).
} 
Indian Ocean. Unfortunately, it was not possible to include representations of the nineteenth-century interactions between East Africa and the Indian subcontinent and with various other territories of the British and Portuguese empires. In light of this circumstance, the editorial team changed the scope of the dossier to its current form, with a focus on Goa.

Within Portuguese nationalist accounts of empire, focused on the sixteenth to eighteenth centuries, the Indian subcontinent and the western Indian Ocean were formerly unattended spaces, seen as inconsequential to its shifting fortunes. However, the epithets of stasis emanating from economistic and essentialist perspectives have since been dislodged. In contrast to the preceding lack of attention to such possibilities, research that has appeared over the last two or three decades, however nascent its formulations, has lent some historical and theoretical definition to this area. Histories of individuals and of processes, whose significance was not primarily determined by their contribution to the imperial economy, peopled emergent accounts. Distinctive and contesting attributes of the century have emerged in the areas of landscape and visual culture, law, print and literary production, the history of medicine, anthropology, agricultural policy, and political history.

The following account points to some of the defining features of the century: events that shaped state politics as well as some of the central contradictions and conflicts whose manifestations stretched across the century and monopolised representations of it. It includes processes such as migration that resulted from the nature of economic and political transformations within the century but remain underrepresented in dominant histories despite the economic significance of these changes and the numbers of people affected by them.

The historiography of the century was framed overwhelmingly by both British and Portuguese imperial narratives, which narrativised each other's impact on India and on world history to favour the ascendancy of the British. Indian nationalist accounts and postcolonial studies that have focused on the British presence on the Indian mainland were later influential frameworks. These enabled and also occluded the recognition of constitutive aspects of the history of Portuguese territories in India (Ferrão, 2014a). The contributions to this dossier indicate how recent work has found alternate approaches to nineteenth-century history.

\section{Markers of Nineteenth-Century History}

Goa had ceased to be the administrative centre for Mozambique in 1752, a condition that facilitated the absorption of the East African territory into trade with Brazil. This decision was taken as part of the vast programme of 
structural reforms devised for the metropolis and the empire by the Marquis de Pombal, the influential Prime Minister to José I appointed in 1750, whose prominence continued after the monarch's death in 1777 and into the reign of Maria I. The interruption imposed by the transfer of the court to Brazil in 1808, and the subsequent revolutions, leaves uncertain the question of the actual scale and success of Pombaline reforms. Although much of what is distinctive about the nature of institutions and power in the nineteenth century flows from the constitutional struggles in its opening decades, the gap between the historiography of earlier centuries and the nineteenth century has left the question of residual intellectual influences from prior periods relatively unexplored.

In studies that consider the nature of the state and its intervention as an agent of change, two conventional brackets usually define the political history of the nineteenth century: the Liberal Revolution of the 1820s, extending for two decades, and the establishment of the Portuguese Republic in 1910. These two events tend to provide a rationale and an interpretive framework within which the varied dimensions of actions, associations, and ideological influences have been understood. Political histories indicate that however powerful the initial impetus for intellectual change may have been, such concepts and ideas rarely traveled without being transformed by the prevailing power structures where they took root. Thus, while the ideas of constitutionalism, liberalism, the freedom of the press, and representative electorates took hold and circulated simultaneously in Brazil, Portugal and India, these terms were also placeholders for other processes to unfold (Lobo, 2017; Lustosa, 2000; Sodré, 1999). The contradictions and tensions between being descendentes (Portuguese born in the colonies) or reinóis (metropolitan Portuguese differentiated politically and racially from the descendentes) were different in each territory, just as the divisions produced by race, mestizage, caste, and language were varied in each context. Further, liberalism had different consequences for those registered as slaves in different colonies, as the work of Miguel Bandeira Jerónimo or Cristina Nogueira da Silva has indicated (Jerónimo, 2000; Silva, 2004; Silva and Grinberg, 2011). The fact that constitutionalism and absolutism formed a framework for political action but were also a formal code through which other political divisions were routed as sub-texts is manifest in the volatile print production of the first half of the nineteenth century. The emergence of different political strands and tensions between groups in Goa and their changing configurations and alliances with groups in Portugal through the century and into the early decades of the twentieth have been elaborated by Sandra Ataíde Lobo (Lobo, 2013, 2016). Luís Cabral de Oliveira's account of the role of Goan Catholic elites 
within the judicial system during the late eighteenth and nineteenth centuries points to the process of empowerment of this strata during the liberal period, and their decisive influence in the codification of laws specific to the New Conquests (Oliveira, 2015).

The nomination of Bernardo Peres da Silva as Prefeito (within the new liberal taxonomy, this was equivalent to the head of state), the first indigenous head of state in 1835, reveals the impact of the struggle over liberalism in the metropole and the realignments of power it spurred in colonial or imminently autonomous states such as Brazil. The reforms Peres da Silva pushed through during his seventeen-day reign, his defeat by local interests opposed to his nomination, his flight to Bombay, and doomed attempt to summon support from Bombay, Daman and Brazil for a ship that would sail to Goa to effect a coup, are instances of the nature of state politics at the time (Lobo, 2016). Such volatility characterised both the composition of the state and the norms by which contestation was conducted. Print publications convey an image of a vociferously contested realm limited to political elites, which gradually admitted and represented a wider circle of contributors, including women. This continued until the print market of Bombay at the end of the century crafted a distinctly oppositional identity in bilingual publications in Konkani, English and Portuguese. These presses and publications voiced dimensions of class and caste experience almost invisible in dominant representations.

Concepts introduced through constitutional and electoral struggles came to be owned by colonial elites as they generated complex ideological frameworks through which questions of citizenship, representation, and rights were routed. The refraction of these concepts and terms are visible in the political parties, societies, and associations contesting each other's vision of public life, the political past, and the economic future (Furtado and Cruz, 2011).

The sphere of influence of the predominantly Catholic indigenous Goan elite was carved out in opposition to the descendentes and the mestiço and was simultaneously the ground for intra-caste rivalries. These were scarcely the only lines of difference although the exclusive access to print of these groups makes these contradictions the most visible. Outside of the two dominant castes, other groups have a fragmentary presence in Portuguese or in Marathi print of the period, though, since the late eighteenth century, the New Conquest territories were numerically larger than the Old. Their inclusion is more visible in official records, where questions of sovereignty, law, land rights, religion and worship, agronomy, and troubled border relations were continuously discussed. Dominant castes among these, however, also formed associations and routed questions of Hindu identity, women's rights, education and pedagogy, linguistic politics, land rights and political 
alliances of the future through newspapers and through public associations. Outside of their occasional presence in the land disputes of the New Conquests, and in the newsprint and books emerging from Bombay, lower caste lives and histories of this period until the mid-twentieth century would have to be elicited through oral sources.

A parallel challenge to the legitimacy of the state ran through the length of the century and took the form of armed rebellion by different groups in the recently acquired New Conquest territories. In 1845, a chieftain, in rebellion against the British and the Portuguese states, collected revenue payments from New Conquest villages on the border between Goa and British India on the authority of chits issued in the name of the government of the prince of Sawantwadi (NAI, 1845). Since many territories had been acquired only in the late eighteenth century, the authority of former land administrators and sovereigns, and their links with neighbouring princely states had a lasting impact. These attempts to restore the authority of former powers, though they were both violent and frequent, tend to be discursively subordinated in histories of the period to the concerns of the Old Conquests. The impact of these rebellions on neighbouring villages was often extractive and violent and the Old Conquest elite represented their perpetrators as marauders or rebels. When many members of this elite turned against the state in the late nineteenth century, however, they appear to have extended support to such a rebellion in 1895 (Pratima Kamat, 1999, 2013).

Despite some interventions, there is still no adequate account of this near continuous state of rebellion in the districts of Pernem, Sattari, Bicholim and Sanquelim involving the Desais, Ranes, and the Sawants of Wadi (Pratima Kamat, 1999; Mendes, 1886). ${ }^{2}$ As they militated for the restoration of their sovereignty in the face of revenue interventions by the state in Goa, they also ensured that the border between Portuguese and British India was never quiet. The interaction between the two governments over the management of rebellion is a colourful illustration of the different approaches to colonial justice systems and the understanding of racial and political distance from indigenous populations.

In contrast to the revenue chieftains such as the Ranes or the Desais who led such rebellions, the upper caste Hindu elite were linked to the state as scribes, translators, intelligence agents and through mercantile trade and finance. The latter group consolidated their alliances with caste counterparts in the

${ }_{2}$ Writing in 1864, António Lopes Mendes lists revolts in 1755, 1797, 1806, 1807, 1809, January 1813, May 1813, January 1814, October 1814, 1816, 1822, 1823, 1824, 1845 and 1852-1855 (Mendes, 1864: 111-112). 
New Conquests and forged a distinct political identity through Marathi print financed initially by the Bombay print market. Later bilingual Portuguese and Marathi newsprint hosted a set of interests and agenda distinct from the Catholic elite who until the early twentieth century, had near exclusive representation in the electoral and higher education realm.

The century can be characterised as one preoccupied with questions of land. Aside from the rebellions of the New Conquests, conflicts over the fate of the hereditarily administered village level gaunkaris, or comunidades, persisted throughout the century (Dias, 2004; Varsha Vijayendra Kamat, 2009; Pereira, 1981). In the New Conquests, caste hierarchies were enforced and challenged through conflicts over the claims to managing temple properties made by different caste groups, as well as over membership in the gaunkari (Magalhães, 2012). Questions of ritual hierarchy and spatial displacement tended to be invisible in representations in Portuguese print, not for linguistic reasons as much as the alienation of state and elite discourse from these domains of power until they acquired the form of legal disputes or revolts (Xavier, 1852). The New Conquests became the object of policies and studies seeking to demonstrate the effectiveness of new scientific and economic practices applied to agriculture and forestry. Similarly, the state's attempt to codify 'uses and customs' of the Hindu population, which opened up a channel for petitioning to the state, constitutes the official representation of processes that appear differently in perspectives emerging from other sources.

A challenge for nineteenth-century history has been to capture the nature of power structures that were new, along with those that had long preceded the nineteenth century but had assumed new dimensions. An instance of this is the fate of the Real Padroado Português, a structure that secured the prerogative of the Portuguese monarchs over the administration of the dioceses and archdioceses established by the Catholic Church in its conquests (Archdiocese of Goa and Daman, 1925). The challenge to the Padroado, presented in the form of the Vatican initiative, the Propaganda Fide (officially instituted in 1622), empowered secular orders of clergy (not affiliated to 'national' religious orders) to administer parishes within Portuguese colonies. The effect of the Propaganda Fide was to regulate and contain the power of the Padroado, and though the struggle between the two had begun centuries before, it was the nineteenth century which witnessed bitter public battles over jurisdiction across various churches and populations in the south of India and its western coast. The thrust towards diluting the national definition of the Roman Catholic ecumene was located in efforts to alter the jurisdictional powers of the earlier orders. This reorientation created the conditions for indigenous clerical dissent in opposition to hierarchies of race, language, economic access 
and caste within the church. The formal categories through which these conflicts were voiced remained those of the Padroado and the Propaganda, but they also found alternate expression in architectural symbolism, linguistic disputes, and political identities such as that of the East Indians in Bombay (Aapan Kon? (Who are We?), 1891; Mello, 1938; Gomes, 2010, 2011).

In several of the disputes outlined above, whether representations of land or the disputes over the Padroado, the interests and representations of indigenous and colonial actors were framed by the discourses of the ascendant British colonial power, interlaced with the changed nature of Portuguese colonial rule. This power relationship inflected pre-existing contact across the western coast of India, port cities of the Arabian Sea and east African territories both British- and Portuguese-held. Colonial elites and migrants who travelled as administrators, priests, traders, professionals, labourers and politicians mediated and were shaped by the nature of colonial interaction in the nineteenth-century history of contact between these territories. In her latest book and in her current research on an earlier period of the nineteenth century, Margret Frenz combines archival sources with oral testimonies to explore migrations from Goa to East Africa, and subsequently to Europe and America. In Community, Memory, and Migration in a Globalizing World. The Goan Experience, c. 1890-1980, she traces the manner in which people recall their lives at different moments in the history of colonialism, how they experienced their social positions in a different context, and discusses how these are related structurally to the history of empires (Frenz, 2014). Selma Carvalho's work on the Goan diaspora in East Africa was published as part of the Oral Histories of British Goans project between 2011 and 2014 (Carvalho, 2010, 2014). Aside from recordings of the oral testimonies of those who migrated to Kenya, Uganda and Tanzania before their relocation to the United Kingdom archived at the British Library, self-published individual memoirs increasingly provide a rich source of personal accounts recounting the experience.

In the context of the Indian Ocean, the examination of the routes along which people, religious practices and commodities circulated, through both informal and formal networks, has underscored the significance of non-statist histories (Farooqui, 2016; Machado, 2003). As a case in point, the elaboration of the nature and extent of power enjoyed by free Africans in India, as opposed to the enslaved, for example, implies a rethinking of the term diaspora as well as the racial composition of the Indian subcontinent. The existence of different systems of slavery and/or forced work in colonies and kingdoms of the Indian Ocean region demand an accounting of the simultaneity and complexity of political and legal categories for slavery often believed to have 
succeeded each other (Allen, 2017; Campbell, 2003; Suzuki, 2017). The field also disturbs dominant spatial chronologies in areas such as the history of Islam, which remained focused on the region of West Asia despite the numerical and cultural significance of Islamic practice in other regions, including East Africa (Kooriadathodi, 2016). Temporal intervals such as the duration of slave voyages, which changed the lives of those on ships carrying slaves as cargo as well as those of itinerant traders and pirates, have been foregrounded to emphasise their elision in nation- and land-centric accounts. To this we can add the identities of those whose nationalities and political affiliations straddled East Africa and India, none of which as yet interrupt supremacist narratives of nation formation on the Indian subcontinent (Allen, 2003).

The field represents conceptual interventions that are too varied and numerous to be consolidated as an alternate centre or to be positioned as a uniformly predictable conceptual margin. In the field of print studies, Isabel Hofmeyr's work, which observed that literary theory tended to use a "non-materialist theory of texts" instead followed connotations to texts that may have had an Anglo-European origin across their unexpected trajectories in political communities of the Indian Ocean (Ferrão, 2005, 2014b; Hofmeyr, 2001). The numerous dimensions of texts, whether oral or written, the circumstances of production, and the contexts of their reception challenged the divisions between centres and peripheries of intellectual influence.

\section{Knowledge Production and Representation}

A characteristic feature of the nineteenth century was the articulated desire to see an organic link emerge between knowledge production and governance. This was elaborated in representations that hoped to see institutions linked to the state reorganised according to principles of political economy, rationalisation and productivity. Residual intellectual traditions and institutional formations particular to Portugal continued to be influential, however, even if their legitimacy was being challenged by intellectual currents associated with Britain and northern Europe.

Histories of architectural history, urbanism and landscape indicate how the desire for new knowledge practices was linked to the representation of the Portuguese empire in India (Mattoso and Rossa, 2010). The epithets of stasis and inertia mentioned earlier were often substantiated in public discourse (and often in English) by gesturing to the physical decadence of Old Goa and the conflicted mid-century move of the capital to Panjim. The abandonment of Old Goa by everyone but the regular clergy and those connected to the Arsenal da Marinha occurred between the end of the seventeenth century and the beginning of the eighteenth century. 
In 1843 (after the expulsion of the religious orders in 1834), the Metropolitan Government decided not only to recognise the relocation of the capital to Panjim but also to prepare a plan whose execution would shape its development (Faria, 2007). The dismantling and the reuse of building materials and architectural elements and ornaments in the buildings of Panjim was regulated and, in some cases, manufactured anew, and accounts for the virtual disappearance of the urban fabric of Old Goa, including its huge perimeter wall.

This account of planned urban renewal is a far cry from the abundant descriptions of Goa's physical decrepitude and decadence that were used as ekphrastic contrasts to the urbanisation of other South Asian capitals in British colonies. The emergence of Panjim reveals the rhetorical function of images of decadence across a century in which a capital was in fact reborn. This rebirth is also significant because the new urban landscape signified a transformed political order within Goa. It was no longer a landscape that by default denoted an absolutist Catholic monarchy committed to evangelising proselytism. Instead, the symbolic connotations to its architecture were the focus of attention for a patrician government trying to expand the participation of civil society within the restricted liberal regime that it represented.

Paulo Varela Gomes points to the influence of British India on nineteenth-century architecture but argues that church architecture was more resistant to this influence than other kinds of visual practices (with the neo-gothic church of Saligão as an exception to this pattern) (Gomes, 2011). Comparatively, domestic architecture, in particular the multilayered nature of domestic spaces, has received more attention from authors. The nineteenth century saw the construction of numerous Goan Catholic aristocratic houses that changed the rural landscape (Carita, 1995; Sampaio, 2011; Silveira, 2007).

The rural landscape was refigured through two impetuses, one of which was to treat natural elements as visual objects, provoking a change in the perception of landscape, while the other was to enhance productivity and to introduce contemporary international innovations in agricultural science to the colonies. The natural vegetation framing Panjim's Altinho and the areas of Aguada and Reis Magos were introduced or modified to perform the role of visual elements that would create perspectives for these sites. This was accompanied by increased significance accorded to surveys, publications and projects by agronomists trained in Lisbon and in British institutions.

The history of this period saw the creation of many institutions associated with modern governance: the creation of the military academy in 1817, which included engineering courses, the reintroduction of the printing press, and the appearance of the first of many journals, the Gazeta de Goa in 1821; the creation of a public library in 1832, and a medical school in 1842 gave Panjim's 
urban landscape its character and design, and nurtured a local urban elite that had participated in its vision and inhabited these new institutions. A number of engineers, physicians, lawyers and judges were trained in Goa and occupied significant posts in other Portuguese colonies (Bastos, 2008; Faria, 2007, 2012, 2014). ${ }^{3}$ Cristiana Bastos' work on the medical school of Goa and the position of Goan medical doctors in Portugal and colonies such as Mozambique and their links with Brazil reveals the hierarchisation of colonial spaces in relation to each other, with Portugal occupying the space of an exclusive validating authority, designed to distribute greater or reduced authority to subordinate doctors and medical institutions in Goa (Bastos, 2005, 2008). The creation of the department of public works in 1869 reinforced this role, enabling the construction of public facilities and infrastructure in the Indian Ocean territories, from Mozambique to Timor. ${ }^{4}$ Descendentes and indigenous Goans occupied positions of authority and initiated public administrative projects.

This elite could be deployed as a sub-colonising phalanx in East Africa while they were systemically subordinated to corresponding educational institutions in Portugal, which in the case of most disciplines such as law and medicine retained the prerogative to confer higher degrees. A similar relationship developed in relation to British territories in the region where educated Goans found institutes of higher education and avenues of employment, while the British colonial state mined the abilities of educated migrants whose training had been financed by a diminished political power.

Military reforms, the railway in 1882, policies regarding schools, and the Anglo-Portuguese treaty were some of the state mechanisms to turn Goa and Indian Ocean territories into an economically profitable enclave for the British. The manner in which Mozambique acquired territorial definition was a drastic shift from the prior existence of a few trading posts along the coast (the islands in the North, the bay of Lourenço Marques in the South, which provided a natural gateway to the hinterlands, initially encompassed the Portuguese presence in the area). In the 1890s a railroad and a harbour were part of the ambitious urban plan that structured the colonial and modernist core of the city of Lourenço Marques/Maputo, and in 1898 the capital moved from the island of Mozambique. The capital city became the harbour to which raw resources were transported, just as in Beira and Nacala in Mozambique and in Lobito (Angola) and Goa. Like Vasco and Lourenço Marques/Maputo, other port cities were founded from

\footnotetext{
${ }^{3}$ Faria traces this statistically within an ongoing project entitled "Building the Portuguese Empire in the 19th century. Public Works across the Indian Ocean and China Sea (1869-1926)".

${ }^{4}$ Much of this was undertaken during the governorship of José Ferreira Pestana (1848-1851 and 1864-1870).
} 
Cape Verde (Mindelo) to Dili (Timor) to mark a new stage in colonial rule, in which the construction of the port of Macau infrastructure is included.

The mediation of colonialism through the production of trained elites was a process which spanned nearly a century, from the administrative independence of Mozambique in 1752 to that of Macau (including Timor) in 1844 from Goa. These events present us with a chronological period that prompts questions about the impetus for change in concepts of governance as well as the need to understand the overarching conception of race and the distribution of social and cultural capital that framed this inter-colonial relationship.

\section{Print and Circulation}

Modern institutions also transformed caste practices, endowing them with new dimensions. An unusual instance of this encounter is elaborated in Filipa Lowndes Vicente's Outros orientalismos (Vicente, 2012). Vicente details the context of a photograph taken in Bombay of the Italian linguist and Indologist, Angelo de Gubernatis, who had just been made a 'brahman' through a ceremony performed by one of the three other figures in the photograph. Among those photographed was the well-known Goan doctor and Indologist, Gerson da Cunha. Vicente's account of the conflict over the photograph and the history of its production and circulation reveals how bodies carried perceptible marks of caste, and how the photograph, as another form of representation, inflected the reading of caste marks. It describes the ritual that preceded the taking of the photograph and the manner in which the circulation of the image legitimised the European 'brahman' and some of the indigenous figures in the picture, while it simultaneously threatened the status of other participants. Not only does this account include preexisting cultures of perception and representation in the analysis of the image, but it also indicates how visual culture as a lived practice was transformed when caste rituals were introduced to new forms such as commercial photography.

Orientalist and reformist frameworks that informed intellectual production of the period had an unquestionable prominence. Studies such as Vicente's indicate, however, that the newness of the nineteenth century also lay in its incorporation of and continuity with prior and contemporary practices. The intelligentsia's focus on expanding the scope of classification and study is characterised by the voluminous mid-century production of the secretary to the Governor General, J. H. da Cunha Rivara, and the Goan government official, Felipe Nery Xavier. Their publications demonstrate how the history of custom, language, land reform and rebellion could be the subject of knowledge accumulation that was directed to the state but did not always shape state policy (Cunha, 1881; Rivara, 1875; Souza, 1879; 
Xavier, 1852). Counter histories appeared as private publications to challenge the intentions of the state or the rival representations of indigenous writers (Gonçalo de Magalhães Teixeira Pinto, 1859). A memorable and extreme version of these was the vituperative writing of Pe. António Francisco Xavier Álvares, the dissenting nationalist priest associated with various publications, among them the periodical O Brado Indiano (Rochelle Pinto, 2007).

The nineteenth century was characterised by public and vocal disregard of dominant perspectives on language, politics and economy, even while the latter were being consolidated in institutions and in legislation across the empire. The discourses of those in authority had been challenged before, but the contestations of official representations and their circulation in print constituted new public arenas. New participants in this arena challenged the linked terrain of knowledge and governance that defined the century. Thus, the English, Hindustani, Konkani, Swabili Vocabulary, which appeared in 1902 in Nairobi to assist Kenyans and Indian migrants settled in British East Africa in the previous century, was indifferent as to whether its orthography had met the test of etymological purity with which linguists and educationists were increasingly concerned (Bir, 1902). Letters to a Bombay newspaper in 1894 declared that the Portuguese-Konkani dictionary published by a reputed Goan linguist, Sebastião Rodolfo Dalgado, was of no use to readers because it was filled with difficult words from other languages and was too expensive (Lorçu, 1894).

An attention to print as a methodological perspective no longer takes for granted traditional distinctions between literature and other forms of representation, as these divisions assume that practices and genres were reproduced identically across all cultural contexts. Nineteenth-century journals and critical articles did prescribe a conventional domain of letters and of the literary, and literary production itself consisted of adaptations of European literary patterns (Garmes, 2004 , 2011). However, it simultaneously borrowed representational forms from across genres such as ethnography, orientalist verse, satire, and prose and gave them aesthetic coherence through the novel (Rochelle Pinto, 2018). In contrast to histories that tended to represent literature as though it was produced exclusively in one language, recent work accounts for a multilingual literary sphere, diglossia and parallel and oppositional literary realms. Thus, even where the object of study may be the world of Portuguese or Konkani or Marathi writing, such accounts acknowledge the existence of literary work in other languages in use, such as English or French (Fernandes, 2010; Passos, 2010; Sardesai, 2006). 


\section{Emerging Histories and Perspectives}

The preeminence of caste discourse in the writings of the elite across the century is just one facet of the modern dimension caste relations had acquired. Recent work on the political visibility and success of non-brahmin castes in the first election in independent Goa raises a pressing question for nineteenth-century history (Parobo, 2015). It demands an account of spheres of influence and the circulation of capital that would allow for this mid-twentieth-century emergence and points to the exclusivity of source material that has generated accounts of the nineteenth century. Likewise, the attention to the Gomantak Maratha Samaj in Anjali Arondekar's recent work, for instance, inverts the image of the bailadeira or devadasi as the subject of reform. Instead, it demands an accounting of kinship structures through which devadasis could claim the name of their patron, of the routes of their capital, and of conceptions of servitude, be it slavery or labour. This would provide a more dynamic account of how caste and sexual hierarchies and state discourses could be negotiated (Arondekar, 2012).

The transition from seeing these groups as bailadeiras to seeing them as members of the Samaj is a shift in perspective enabled by sources in languages such as Marathi. The Samaj's proximity to social capital and their ability to use capital to represent themselves in print or through identity-based organisations indicates that some alternate perspectives were available within restricted spheres of circulation. While legal relations to the temple economy and space and to village land are visible in the realm of Portuguese print, questions of sexuality and slavery remain part of the social legacy that can be known only through interactions, and through oral cultural practices, ritual and festivals (Jason Keith Fernandes, 2015). Electoral victories and formal associations fit modern categories of political action more comfortably than those lower caste groups who could not represent themselves in these forms.

Another kind of methodological challenge is posed by the absence of an adequate account of racial difference and its absorption within indigenous society or of the silence surrounding its presence. Official records register the presence of different racial groups in nineteenth-century censuses and police records, and Cristina Nogueira da Silva traces the ambiguities in concepts of law and citizenship over the question of slavery. However, the disappearance of race as a category of difference within indigenous society by the early twentieth century is yet to be explored (Chatterjee, 1999; Guha, 2013).

The fragmentary appearance of non-dominant perspectives in nineteenthand early twentieth-century print has, by its scarcity and difference, repositioned the authority we accord conventional accounts and drawn attention to the limits of official representation itself. As with British colonialism in India, 
anthropological studies with a focus on the contemporary have revealed how state accounts created dominant categories that limit our understanding of colonial society (Siqueira, 2006).

The four articles and the book review of this dossier reveal how theoretical advances in different periods of Portuguese imperial history continuously inform each other. Ricardo Roque's account of the recirculation of Garcia da Orta's canonical botanical text, Colóquios dos simples e drogas da Índia of 1563 for instance, provides a retrospective overview of the field of botanical medicine. His comparison between sixteenth-century mechanisms to validate unfamiliar knowledge systems and nineteenth-century ones delineates how through a process of 'translation', medical knowledge was appropriated by western knowledge structures and indigenous practitioners excluded and erased from the history of its production. In doing so, Roque's essay references the expanding field of sixteenth-century studies that elaborates the manner in which the encounter with colonial difference was managed. It also demonstrates how nineteenth-century science separated knowledge from its context of production to sustain a conception of universality.

José Miguel Moura Ferreira's study of afforestation policies in the New Conquests further elaborates the conjunction between governance and scientific perspectives on forestry and agriculture, thus contributing a valuable comparative account of the scale and effect of similar initiatives in British India. Ferreira notes that a similar approach to bringing such land under the purview of state policy was attempted in the eighteenth century but may have been disrupted by the political events of the early nineteenth. By the mid-nineteenth century, however, he notes how this perspective was adopted by the Goan elite, leading to an increase in the number of formal associations and publications devoted to this area.

Filipa Lowndes Vicente's essay on the catalogue of the industrial exhibition of 1860 in this volume extends some of the methodologies used in her prior work on visual culture. It details the history of objects and categories mentioned and gauges the significance of the exhibition in the light of the international trend in showcasing colonial beings and objects for metropolitan audiences. Her tracing of the context of production of these objects helps illuminate the early interpellation of Goa into global discourses linking public exhibitions and industrialisation. Hélder Garmes' review of Filipa Vicente's Entre dois impérios. Viajantes britânicos em Goa (1800-1940), which emerged at the end of 2015 (Lisboa: Tinta-da-China) highlights the book's overview of travel narratives of nineteenth- and twentieth-century Goa, in particular British accounts from this period. 
He discusses the attempt to trace the locus of difference in writing by men and women while deconstructing the prejudices through which nineteenth-century British travellers saw and wrote about Goa.

In contrast to Ricardo Roque's essay, which invokes sixteenth-century historiography, Jason Keith Fernandes' essay on Wamanrao Varde Valaulikar (1877-1946) indicates how the pressures of nationalist discourses in the twentieth century generates an interest in its precursors and determining influences in the nineteenth. The twentieth century was defined by the increasing intensity of varying nationalist positions addressed both to the post-colonial Indian state and to the colonial state in Goa. Language associations became vehicles of identity formation providing upper caste intelligentsia with access to state institutions and policy formation. The formation of linguistic states made language the bearer of symbolic value that consolidated dominant identities. It is in this context that the essay revisits the hagiographic representations of the late nineteenth-century personality, known familiarly as Shenoi Goembab. By presenting Valaulikar's investment in crafting a Gaud Saraswat Brahmin identity through script and language, the essay explores a political formation whose discursive antecedents can be traced back to the mid-nineteenth century.

This selection of essays thus demonstrates how the historiography of the nineteenth century has extricated itself from some of the representational structures that formerly shaped it. While some aspects have been elaborated sufficiently to generate layered critiques and detailed accounts of particular aspects, others still await further exploration that can generate frameworks to enable future work. While this dossier is restricted to work on Goa, the essays and review indicate how political events and representations in each territory reverberated through Portuguese and British territories in East Africa and the Persian Gulf, and not the least in Portugal itself.

\section{Edited by Scott M. Culp}

\section{References}

Aapan Kon? (Who Are We?) (1891). Bombay: Native Opinion Press.

Allen, Richard B. (2003), "The Mascarene Slave-Trade and Labour Migration in the Indian Ocean during the Eighteenth and Nineteenth Centuries", Slavery and Abolition, 24(2), 33-50.

Allen, Richard B. (2017), "Ending the History of Silence: Reconstructing European Slave Trading in the Indian Ocean", Tempo, 23(2), 294-313.

Archdiocese of Goa and Daman (1925), In the Mission Field: The Diocese of Damaun. Bombay: The Times Press. 
Arondekar, Anjali (2012), "Subject to Sex: A Small History of the Gomantak Maratha Samaj”, in Ania Loomba; Ritty Lukose (eds.), South Asian Feminisms: Contemporary Interventions. Durham: Duke University Press, 244-263.

Bastos, Cristiana (2005), "Race, Medicine and the Late Portuguese Empire: The Role of Goan Colonial Physicians”, Journal of Romance Studies, 5(1), 23-35. Accessed on 08.01.2018, at https://www.academia.edu/5452334.

Bastos, Cristiana (2008), "From India to Brazil, with a Microscope and a Seat in Parliament: The Life and Work of Dr. Indalêncio Froilano de Melo”, Journal of History of Science and Technology, 2, 139-189.

Bir, Pedro M. F. C. (1902), A Handbook of the English, Hindustani, Konkani, Swabili Languages. Nairobi: Uganda Railway Press.

Campbell, Gwyn (2003), Structure of Slavery in Indian Ocean Africa and Asia. London/ /Portland: Routledge [1 ${ }^{\text {st }}$ ed.].

Carita, Hélder (1995), Palácios de Goa: modelos e tipologias de arquitectura civil indo-portuguesa. Lisboa: Quetzal.

Carvalho, Selma (2010), Into the Diaspora Wilderness. Goa: 1556 Trust.

Carvalho, Selma (2014), A Railway Runs Through - Goans of British East Africa, 1865 -1980. Margao: Cinnamon Teal.

Chatterjee, Indrani (1999), Gender, Slavery and Law in Colonial India. New Delhi: Oxford University Press.

Cunha, J. Gerson da (1881), The Konkanî Language and Literature. Bombay: Govt. Central Press.

Dias, Remy (2004), The Socio-Economic History of Goa with Special Reference to the Communidade System: 1750-1910. Doctoral Thesis, Taleigaon, University of Goa. Accessed on 25.08.2016, at http://shodhganga.inflibnet.ac.in/handle/10603/32428.

Faria, Alice Santiago (2007), "Panjim between the Past and Modernity: Building the City of New Goa, 1776-1921”, Murphy, Journal of Architectural History and Theory, 2(July), 66-97.

Faria, Alice Santiago (2012), "O papel dos luso-descendentes na engenharia militar e nas obras públicas em Goa ao longo do século XIX”, in Artur Teodoro Matos (ed.), Goa: passado e presente, Tomo I. Lisboa: Centro de Estudos dos Povos e Culturas de Expressão Portuguesa da Universidade Católica Portuguesa/Centro de História de Além-mar, 225-237.

Faria, Alice Santiago (2014), Architecture coloniale portugaise à Goa: le département des travaux publics, 1840-1926. Saarbrüchen: Presses Académiques Francophones.

Farooqui, Amar (2016), “The Global Career of Indian Opium and Local Destinies”, Almanack, 14, 52-73.

Fernandes, Andre Rafael (2010), When the Curtains Rise - Understanding Goa's Vibrant Konkani Theatre. Panaji: Tiatr Academy of Goa. 
Fernandes, Jason Keith (2015), "Rethinking Origin Myths in Goa”, oHeraldo, 17 April. Accessed on 22.06.2017, at https://www.heraldgoa.in/Edit/Opinions/Rethinking-origin-myths-in-Goa/87380.html.

Ferrão, Rodney Benedito (2005), "Goan Identity in Novels that Connect India, Africa and the West”. MPhil. London: Birkbeck.

Ferrão, Rodney Benedito (2014a), "Tempestuously Goan: The Inability of Erasure between Prospero and Caliban”, in Everton V. Machado; Duarte Drumond Braga (eds.), ACT 27 - Goa portuguesa e pós-colonial: literatura, cultura e sociedade. Lisboa: Húmus/CEC.

Ferrão, Rodney Benedito (2014b), “The Other Black Ocean: Indo-Portuguese Slavery and Africanness Elsewhere in Margaret Mascarenhas's Skin”, Research in African Literatures, 45(3), 27-47.

Frenz, Margret (2014), Community, Memory, and Migration in a Globalizing World: The Goan Experience, c. 1890-1980. New Delhi: Oxford University Press.

Furtado, Max de Loyola; Cruz, Sharon da (2011), "The Partido Indiano and the September Revolt of 1890 in Goa", Economic and Political Weekly, 46(33), 67-75.

Garmes, Hélder (2004), "Origem e estabelecimento da imprensa e da literatura em Goa”, Oriente, Engenho e Arte - Imprensa e Literatura de Lingua Portuguesa em Goa, Marcau e Timor Leste. São Paulo: Alameda Casa Editorial, 15-85.

Garmes, Hélder (ed.) (2011), "De Os brâmanes a Bodki: reflexões sobre o romance goês”, Floema. Caderno de Teoria e História Literária, 9, 73-91.

Gomes, Paulo Varela (2010), “As igrejas dos católicos de Goa”, Ler História, 58, 47-60.

Gomes, Paulo Varela (2011), Whitewash, Red Stone: A History of Church Architecture in Goa. New Delhi: Yoda Press.

Guha, Sumit (2013), Beyond Caste: Identity and Power in South Asia, Past and Present. Leiden/Boston: Brill.

Hofmeyr, Isabel (2001), "Bunyan in Africa Text and Transition", Interventions, 3(3), 322-335. Accessed on 18.01.2018, at https://doi.org/10.1080/713769072.

Jerónimo, Miguel Bandeira de Carvalho (2000), "Livros brancos, almas negras. O colonialismo português: programas e discursos (1880-1930)". Doctoral Thesis, Faculdade de Ciências Sociais e Humanas da Universidade Nova de Lisboa, Lisboa, Portugal.

Kamat, Pratima (1999), Farar Far: Local Resistance to Colonial Hegemony in Goa, 1510-1912. Panaji: Institute Meneses de Bragança.

Kamat, Pratima (2013), "The Goa-Ceylon Religious Connection: A Review of the 'The Indian Cry' of Alvares Mar Julius, Archbishop of Ceylon, Goa and India”, Sabaragamuwa University Journal, 12(1), 61-82.

Kamat, Varsha Vijayendra (2009), "Usurpation of Feudal Rights by the Colonial State in Medieval Goa", Proceedings of the Indian History Congress, 70, 363-371.

Kooriadathodi, Mahmood (2016), "Cosmopolis of Law: Islamic Legal Ideas and Texts across the Indian Ocean and Eastern Mediterranean Worlds”. Doctoral 
Thesis, Universiteit Leiden, Leiden, Nederland. Accessed on 06.01.2018, at https:// openaccess.leidenuniv.nl/handle/1887/44973.

Lobo, Sandra Ataíde (2013), “O desassossego goês: cultura e política em Goa do liberalismo ao acto colonial”, Doctoral Thesis, Faculdade de Ciências Sociais e Humanas da Universidade Nova de Lisboa, Lisboa, Portugal.

Lobo, Sandra Ataíde (2016), "O sujeito, o cidadão e o colonizador na Goa dos séculos XIX-XX”, in Ângela Barreto Xavier; Cristina Nogueira da Silva (eds.), O governo dos outros: poder e diferença no império português. Lisboa: ICS - Imprensa de Ciências Sociais da Universidade de Lisboa, 293-322.

Lobo, Sandra Ataíde (2017), "The Languages of the Goan Periodical Press, 1820-1933”, in José Garcia; Filipa Subtil; Chandrika Kaul; Alexandra Santos (eds.), Media and the Portuguese Empire. London: Palgrave Macmillan, 69-86.

Lorçu (1894), "Diccionario Concanim Portuguez, Philologico Etymologico do emo. e revmo. Monsenhor Sebastião Rodolpho Dalgado", O Concanim, July 8.

Lustosa, Isabel (2000), Insultos impressos: a guerra dos jornalistas na Independência, 1821-1823. São Paulo: Companhia das Letras.

Machado, Pedro (2003), "A Forgotten Corner of the Indian Ocean: Gujarati Merchants, Portuguese India and the Mozambique Slave-Trade, c. 1730-1830", Slavery and Abolition, 24(2), 17-32.

Magalhães, Manuel João (2012), Pequenos reis e grandes honras: culto, poder e estatuto na Índia Ocidental. Lisboa: Escola de Ciências Sociais e Humanas, ISCTE - Instituto Universitário de Lisboa.

Mattoso, José; Rossa, Walter (2010), Portuguese Heritage around the World: Architecture and Urbanism. Asia and Oceania. Lisboa: Fundação Calouste Gulbenkian.

Mello, John de (1938), Some Materials for a History of the Bombay East Indian Community. Mumbai: Gem Printing Works.

Mendes, António Lopes (1864), Apontamentos sobre a provincia de Satary do estado da Índia Portugueza. Nova Goa: Imprensa Nacional.

Mendes, António Lopes (1886), A Índia portugueza: breve descripção das possessões portuguezas na Asia, vol. I. Lisboa: Imprensa Nacional.

NAI - National Archives of India (1845), Foreign and Political Records.

Oliveira, Luís Pedroso de Lima Cabral de (2015), “A consagração dos naturais: direito(s) e elites naturais católicas em Goa (1780-1880)", Doctoral Thesis, Faculdade de Direito da Universidade Nova de Lisboa, Lisboa, Portugal. Accessed on 22.03.2018, at https://run.unl.pt/handle/10362/16336.

Parobo, Parag D. (2015), India's First Democratic Revolution: Dayanand Bandodkar and the Rise of the Babujan in Goa. Telangana, India: Orient Blackswan [1 $1^{\text {st }}$ ed.].

Passos, Joana (2010), "Resistência e assimilação colonial na prosa goesa do século XIX”, Portuguese Literary and Cultural Studies, 17/18, 99-115. 
Pereira, Rui Gomes (1981), Gaunkari: The Old Village Associations, vol. II. Panjim, Goa: A. Gomes Pereira, Printwell Press. Translated by Angelo das Neves Souza.

Pinto, Gonçalo de Magalhães Teixeira (1859), Memórias sobre as possessões portuguezas na Asia. Nova Goa: Imprensa Nacional.

Pinto, Rochelle (2007), Between Empires: Print and Politics in Goa. New Delhi: Oxford University Press India.

Pinto, Rochelle (2018), "Settling the Land: The Village and the Threat of Capital in the Novel in Goa", in Supriya Chaudhuri; Josephine McDonagh; Brian H. Murray; Rajeswari Sunder Rajan (eds.), Commodities and Culture in the Colonial World. Abingdon, England: Routledge, 100-112.

Rivara, Joaquim Heliodoro da Cunha (1875), A conjuração de 1787 em Goa, e varias cousas desse tempo: memoria histórica. Nova Goa: Imprensa Nacional.

Sampaio, Lígia (2011), "Casas cristãs da Taluka de Salsete: Goa”, Masters Dissertation, Faculdade de Letras da Universidade do Porto, Porto, Portugal.

Sardesai, Madhavi (2006), "A Comparative Linguistic and Cultural Study of Lexical Influences on Konkani”, Doctoral Thesis, Goa University, Taleigão, India.

Silva, Cristina Nogueira da (2004), "Missão civilizacional e codificação de usos e costumes na doutrina colonial portuguesa (séculos XIX e XX)", Quadernifiorentini, 33/34, 899-919.

Silva, Cristina Nogueira da; Grinberg, Keila (2011), "Soil Free from Slaves: Slave Law in Late Eighteenth- and Early Nineteenth-Century Portugal”, Slavery \& Abolition, 32(3), 431-446. Accessed on 20.01.2018, at https://doi.org/10.1080/0144039X.2011.588480.

Silveira, Ângelo Luís Costa (2007), A casa-pátio de Goa. Porto: FAUP - Faculdade de Arquitetura da Universidade do Porto [1 ${ }^{\text {st }}$ ed.: 1999].

Siqueira, Alito (2006), “Goa: do ocidentalismo ao pós-colonialismo”, in Rosa Maria Perez (ed.), Os portugueses e o oriente: história, itinerários, representações. Lisboa: Dom Quixote.

Sodré, Nelson Werneck (1999), História da imprensa no Brasil. Rio de Janeiro: Mauad Editora Ltda.

Souza, Felippe Nery Thomé Caetano do Rosario e (1879), Noticia historica e legislação da instrucção publica primaria, secundaria e superior na India portugueza. Nova Goa: Typographia da Cruz.

Suzuki, Hideaki (2017), "The Slave Trade in the Nineteenth-Century Western Indian Ocean: An Overview”, Slave Trade Profiteers in the Western Indian Ocean: Suppression and Resistance in the Nineteenth Century. Berlin: Springer, 19-40.

Vicente, Filipa Lowndes (2012), Other Orientalisms: India between Florence and Bombay, 1860-1900. Telangana, India: Orient Blackswan.

Xavier, Filipe Nery (1852), Bosquejo historico das communidades das aldeas dos concelhos das Ilhas, Salsete e Bardez. Nova Goa: Imprensa Nacional. 
Received on 05.02.2018

Accepted for publication on 26.03.2018

\section{Rochelle Pinto}

Independent Researcher

Contact: rochelle.pinto@gmail.com

\section{Sidh Losa Mendiratta}

Centro de Estudos Sociais da Universidade de Coimbra

Colégio de S. Jerónimo, Largo D. Dinis, Apartado 3087, 3000-995 Coimbra, Portugal

Contact: sidhmendiratta@ces.uc.pt

\section{Walter Rossa}

Centro de Estudos Sociais / Departamento de Arquitetura da Faculdade de Ciências e Tecnologia Universidade de Coimbra

Colégio das Artes, Largo D. Dinis, 3000-143 Coimbra, Portugal

Contact: wrossa@uc.pt

\section{Reenquadrar o século xIX}

Já não exclusivamente determinada pelas vicissitudes do império, a história das colónias portuguesas da Índia e região do Oceano Índico do século XIX foi suficientemente elaborada para que surgissem algumas estruturas heurísticas. Histórias da medicina, antropologia, política, imprensa, migração e escravatura destacam a importância das narrativas não-estatistas ao traçarem o movimento de pessoas, bens e ideias através de redes formais e informais, muitas vezes sob o poder colonial britânico em ascensão. Em conjunto com estudos sobre cultura visual e espacial e política agrária, elas têm ajudado a delinear atributos distintivos e contraditórios que caracterizam o século XIX. Este século continua a representar um desafio historiográfico, já que ele tanto infere como contraria os relatos teóricos dominantes do colonialismo.

Palavras-chave: castas; ciência; colonialismo; Goa; império português.

\section{Recadrer le XIX siècle}

L'histoire des colonies portugaises de l'Inde et de la région de l'Océan Indien du XIX ${ }^{\mathrm{e}}$ siècle n'étant déjà plus exclusivement déterminée par les vicissitudes de l'empire fut suffisamment élaborée pour que puissent apparaître quelques structures heuristiques. Tout un ensemble d'histoires de la médecine, de l'anthropologie, de la politique, de la presse, de la migration et de l'esclavage soulignent l'importance des narratives non-étatiques en retraçant le mouvement des personnes, des biens et des idées à travers de réseaux formels et informels, maintes fois sous le pouvoir britannique en ascension. Concomitamment à des études sur la culture visuelle et spatiale et la politique agraire, elles ont aidé à tracer des particularités distinctives et contradictoires qui caractérisent le XIX ${ }^{\mathrm{e}}$ siècle. Ce siècle reste un défi historiographique puisqu'il contrarie tout autant qu'il conforte les récits théoriques du colonialisme.

Mots-clés: castes; colonialisme; empire portugais; Goa; science. 